\title{
Is There A Way to Prevent Aging? A Study Using Metformin in Blood Sugar Levels and Serum Levels of IGF-1
}

\author{
Adakah Jalan Mencegah Penuaan? Studi Penggunaan Metformin \\ Dalam Kadar Gula Darah dan Kadar Serum IGF-1
}

\author{
Arlina W. Gama ${ }^{* 1}$, Arief Santoso ${ }^{2}$, Ika Yustisia ${ }^{3}$, Nurpudji A. Taslim ${ }^{4}$, Irfan Idris ${ }^{5}$ Isra Wahid $^{6}$ \\ 1, 2, 3, 4, 5, 6 Bagian Ilmu Biomedik, Universitas Hasanuddin, Makassar \\ ${ }^{1}$ Bagian Ilmu Biomedik, Universitas Islam Negeri Alauddin Makassar, Makassar
}

DOI: 10.24252 al-sihah.v13i1.21694

Received: 10 June 2021 / In Reviewed: 15 June 2021 / Accepted: 28 June 2021 / Available online: 30 June 2021 (O) The Authors 2021. This is an open access article under the CC BY-NC-SA 4.0 license

\begin{abstract}
Aging is influenced by lifestyle, which one is by consuming excessive calories. In recent years there have been many studies on aging and age-related diseases, calorie restriction mimetic is one of them. Metformin is a calorie restriction mimetic that is attractive to gerontologists. This research analyzed the effect of metformin as a calorie restriction mimetic on fasting blood glucose and IGF-1 serum levels in old white male Wistar rats. This study conducted with an experimental study with a pre and post-test pattern with controlled group design on male rats (Rattus novergicus) Wistar strain which was divided into 3 groups, control group (K), the calorie restriction group (P1), and the metformin group (P2), 6 rats each group. Blood glucose levels were measured by a glucometer and serum IGF-1 levels were measured with an ELISA kit, where blood samples were taken from the tail of the rats. In general, the provision of metformin and calorie restriction tended to reduce blood glucose levels, but increased serum IGF-1 levels. There is a significant relationship between blood glucose levels and serum IGF-1 levels. It's necessary to conduct further research to determine the effective dose and maximum dose of metformin to reduce blood glucose level and serum IG-1 levels which can be slow down the aging process.
\end{abstract}

\begin{abstract}
ABSTRAK
Penuaan dipengaruhi oleh gaya hidup, salah satunya dengan mengkonsumsi kalori secara berlebihan. Dalam beberapa tahun terakhir telah banyak penelitian tentang penuaan dan penyakit terkait usia, pembatasan kalori merupakan salah satunya. Penelitian ini mengalisa pemberian metformin sebagai restriksi kalori mimetik terhadap kadar glukosa darah puasa dan serum IGF-1 pada tikus putih tua jantan galur wistar Penelitian dilakukan dengan menggunakan desain eksperimental dengan pola Pre and Post test with controlled group design pada tikus putih (Rattus Novergicus) jantan galur wistar yang dibagi menjadi 3 kelompok yaitu kelompok Kontrol (K), Kelompok Restriksi Kalori (P1), dan Kelompok Metformin (P2), masing-masing 6 ekor tikus. Kadar gula darah diukur dengan alat glucometer dan kadar serum IGF-1 diukur menggunakan ELISA kit, di mana sampel darah diambil dari bagian ekor tikus. Secara umum pemberian metformin dan restriksi kalori cenderung menurunkan dan kadar glukosa darah, namun meningkatkan kadar serum IGF-1. Terdapat hubungan yang signifikan antara kadar glukosa darah dan kadar serum IGF-1. Dari hasil penelitian yang telah dilakukan maka perlu diadakan penelitian lebih lanjut untuk menentukan dosis efektif dan dosis maksimum dari metformin untuk menurunkan kadar glukosa darah dan kadar serum IGF 1 yang dapat memperlambat proses penuaan.
\end{abstract}

\section{GRAPHICAL ABSTRACT}

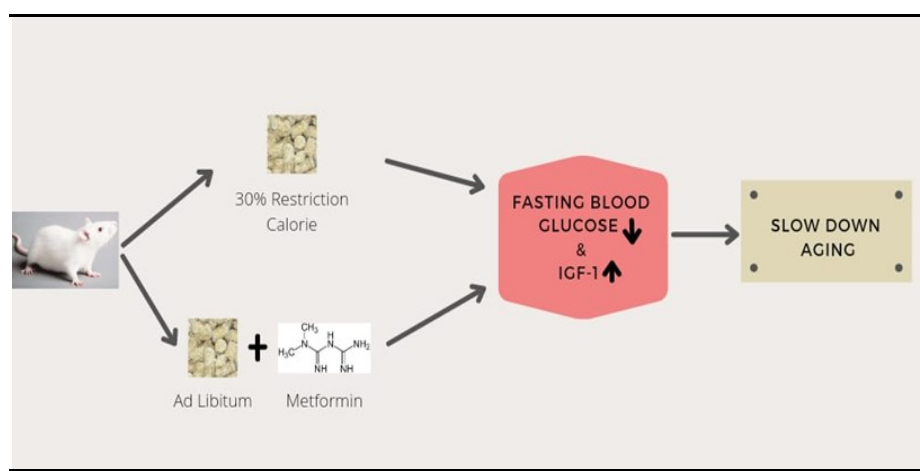

Keyword

anti aging; blood sugar level; calorie restriction mimetic; ig-1 level

\section{Kata Kunci:}

anti penuaan; ig-1 level; kadar gula darah; metformin; restriksi kalori mimetik

\section{* Correspondence}

Perumahan Bumi Tamalanrea Permai Blok E No. 130, Makassar, 90245

Email: arlinawiyata.gama@uin-alauddin.ac.id 


\section{PENDAHULUAN}

Proses penuaan merupakan proses alami dan progresif yang dialami setiap manusia dan tidak dapat dihindari, yang mengakibatkan morbiditas dan mortalitas (Yudiarto \& Sjahrir, 2011; Čepelak, et al., 2019; Harianja et al., 2018). Proses penuaan pada dasarnya adalah penyakit. Empat teori utama yang telah menjelaskan bagaimana proses penuaan itu sendiri. Teori-teori ini meliputi: peningkatan ROS (reactive oxygen species) dan penurunan perbaikan DNA, peningkatan sirkulasi glukosa dan insulin, peningkatan sirkulasi hormone pertumbuhan (growth hormone) dan insulin-line growth factor-1 (IGF-1), dan hipotesis hormesis (Gillespie et al., 2016).

Kondisi lingkungan sekitar termasuk gaya hidup, sangat mempengaruhi laju dari penuaan. Contohnya, Obesitas atau mengonsumsi kalori yang berlebih telah dikaitkan sebagai patogenesis penyakit terkait usia (aged-related disease) seperti diabetes, penyakit kardiovaskular, stroke dan perkembangan kanker (Gillespie et al., 2016; López-Otín et al., 2013)

Penuaan mengakibatkan adanya perubahan sistem endokrin yang ditandai dengan adanya kemunduran dalam pemeliharaan proses homeostatis dari waktu ke waktu, yang menyebabkan terjadinya penurunan fungsi berbagai organ secara bertahap dan peningkatan risiko penyakit serta kematian sel (Vitale et al., 2013; Adams et al., 2015; Niccoli \& Partridge, 2012). Proses kematian sel secara metabolik ditandai oleh resistensi insulin, perubahan komposisi tubuh, peningkatan kadar glukosa dan penurunan fisiologis dari hormon pertumbuhan $(\mathrm{GH})$ dan insulin-like factor-1 (IGF-1) (Cerf, 2013; Graham et al., 2012). Pada awal proses penuaan, sel pankreas memproduksi lebih banyak insulin untuk menjaga kadar glukosa darah tetap normal, namun kondisi hiperglikemia yang terus menurus mengakibatkan terganggunya produksi insulin (Barzilai et al., 2016; Lee \& Halter, 2017).

Beberapa tahun terakhir ini, telah dilakukan banyak penelitian terhadap penyakit yang berkaitan dengan usia, dengan menggunakan penanda molekuler yang dapat membantu kita untuk memahami dasar biologi penuaan, yang nantinya akan dikembangkan sebagai strategi dalam menunda penuaan (Burch et al., 2014; Guerville et al., 2020; Stekovic et al., 2019; Xia et al., 2016). Beberapa penelitian yang dikembangkan saat ini adalah pembatasan kalori (caloric restriction), di mana intervensi yang dilakukan membuktikan bahwa penuaan dan penyakit terkait usia dapat diperlambat (Anderson et al., 2016; Balasubramanian et al., 2017; López-Lluch et al., 2016). Pembatasan kalori (caloric restriction) didefinisikan sebagai pengurangan asupan nutrisi sekitar 20-50\% tanpa menyebabkan kekurangan gizi/malnutrisi (Longo et al., 2015; Solon-Biet et al., 2015).

Pencarian senyawa yang dapat meniru manfaat dari segi kesehatan dan memberikan umur panjang seperti pada pembatasan kalori, tanpa harus mengurangi jumlah asupan kalori merupakan hal yang menarik dalam penelitian nutrisi saat ini. Obatobatan atau senyawa tersebut dikenal sebagai restriksi kalori mimesis (calorie restriction mimetics), di mana senyawa ini berfungsi mencegah penyakit yang berkai- 
tan dengan usia dan dapat membuat hidup lebih sehat dan memperpanjang usia (Smith et al., 2010; Lee et al., 2013).

Metformin merupakan salah satu kalori restriksi mimetik yang menarik bagi gerontologis. Metformin yang merupakan golongan biguanin yang digunakan sebagai obat diabetes tipe 2 yang efek utamanya menurunkan glukosa dengan menghambat proses glukoneogensis di hati, yang dapat meningkatkan sensitivitas insulin dan mengaktifkan AMPK (adenosine monophosphate-activated protein kinase) serta efek menguntungkan lainnya dalam aspek proses penuaan (Lee \& Min, 2013; Madiraju et al., 2018). Mekanisme aksi metformin belum teridentifikasi dengan jelas, namun dapat memberikan pengaruh yang berbeda pula tergantung pada cara dan dosis penggunaannya. Penggunaan metformin dapat dikaitkan dengan penurunan insiden dan mortalitas penyakit yang berhubungan dengan usia dan kanker. Mekanisme metformin sebagai anti hiperglikemik dengan cara menekan oksidasi asam lemak hati, meningkatkan sensitivitas insulin, mengurangi penyerapan glukosa usus, mengurangi proses peradangan dan meningkatkan fosforilasi oksidatif mitokondria melalui jalur AMPK (Barzilai et al., 2016; Madeo et al., 2019). Metformin bekerja di luar dan di dalam sel. Di luar sel, metformin telah terbukti berpengaruh pada reseptor sitokin, IGF-1, insulin, dan adiponektin, yang mana semua jalur tersebut diaktifkan dengan proses penuaan dan ketika dimodulasi memiliki hubungan dengan pertambahan usia (Podhorecka et al., 2017). Metformin juga bekerja di intrase- luler, dengan menghambat jalur inflamasi dan mengaktifkan AMPK, Metformin meningkatkan rasio AMP ke ATP dengan menghambat kompleks mitokondria I, mengaktifkan jalur pensinyalan protein kinase teraktivasi adenosine monofosfat (AMPK) dan menekan jalur reseptor faktor pertumbuhan-1 (IGF-1R)., meningkatkan penghambatan mTOR, yang merupakan target utama dalam memodulasi penuaan. Proses ini secara bersamaan mempengaruhi peradangan, kelangsungan hidup sel, pertahanan stress, autofagi dan sintesis protein yang dapat menjadi hasil biologis terkait dengan penuaan (Barzilai et al., 2016).

Penelitian mengenai efek metformin terhadap kadar IGF-1 telah banyak dilakukan, akan tetapi adanya perbedaan dalam hasil kadar serum IGF-1 melalui pensinyalan reseptor insulin, dalam hal ini kaitannya dengan kadar glukosa darah yang menyebabkan proses penuaan. Oleh karena itu peneliti tertarik melakukan uji eksprimen untuk mengetahui pengaruh pemberian metformin sebagai restriksi kalori mimetik terhadap kadar glukosa darah dan kadar serum IGF-1.

\section{METODE PENELITIAN}

Penelitian ini merupakan penelitian experimental dengan pola pre and post test with controlled group design. Hewan coba dibagi menjadi 3 kelompok secara random acak yaitu 1) kelompok kontrol (K) dengan diberi pakan standar sebesar $10 \%$ dari berat badan tikus 2) kelompok restriksi kalori (P1) yang diberi pakan standard an pengurangan pakan sebanyak $30 \%$ dari total pakan 3) kelompok metformin (P2) yang 
Tabel 1

Rerata Kadar Glukosa Darah Tikus Putih Jantan Galur Wistar

\begin{tabular}{|c|c|c|c|c|c|c|c|c|c|c|}
\hline \multirow{3}{*}{$\begin{array}{l}\text { Variabel } \\
\text { (waktu) }\end{array}$} & \multicolumn{9}{|c|}{ Kelompok } & \multirow[t]{3}{*}{$p$-value* } \\
\hline & \multicolumn{3}{|c|}{ Kelompok Kontrol (K) } & \multicolumn{3}{|c|}{ Kelompok Restriksi (P1) } & \multicolumn{3}{|c|}{ Kelompok Metformin (P2) } & \\
\hline & Min & Max & Mean \pm SD & Min & Max & Mean \pm SD & Min & Max & Mean \pm SD & \\
\hline Hari ke-0 & 59 & 121 & $95,00 \pm 24,43$ & 92 & 123 & $111,00 \pm 11,18$ & 105 & 120 & $113,00 \pm 6,72$ & 0.136 \\
\hline Hari ke-15 & 106 & 138 & $123,33 \pm 11,27$ & 88 & 109 & $97,17 \pm 7,67$ & 98 & 121 & $108,50 \pm 9,33$ & 0.001 \\
\hline Hari ke-30 & 112 & 172 & $141,83 \pm 23,710$ & 69 & 99 & $87,00 \pm 12,31$ & 81 & 105 & $94,17 \pm 7,93$ & 0 \\
\hline
\end{tabular}

diberi pakan standar sebesar $10 \%$ dari berat badan dan metformin sebesar $9 \mathrm{mg} / 200$ grBB per sonde. Sampel penelitian adalah 18 ekor tikus putih (Rattus novergicus) jantan galur wistar berusia 12-18 bulan dengan berat badan 250-300 gram dengan kondisi yang baik. Pemilihan tikus putih jantan (rattus novergicus) galur wistar didasarkan karena hewan ini memiliki kelebihan dan karakteristik fungsional dari sistem tubuh mamalia, dan jantan tidak mengalami siklus estrus sehingga sampel menjadi homogen, serta tidak sulit untuk dikendalikan dan keakuratan hasil dapat diperoleh (Jhonson, 2012). Sedangkan pemilihan usia 12-18 bulan didasarkan usia maksimal tikus galur wistar yaitu 3 tahun (36 bulan), atau setara dengan usia 90 tahun pada manusia, sedangkan proses penuaan terjadi pada usia 30 tahun manusia, atau setara dengan usia 12 bulan pada tikus (Harianja et al., 2018).

Setiap tikus dimasukkan ke single cage bertujuan agar hewan coba dalam kondisi tidak stress, lalu diberikan perlakuan selama 30 hari. Pengambilan sampel darah untuk pemeriksaan kadar glukosa darah dan kadar serum IGF-1 dilakukan 3 kali yaitu pada akhir aklimatisasi (hari ke-0) atau pada saat sebelum diberika perlakuan (pre-test), tengah perlakuan/ mid-test (hari ke-15) dan akhir perlakuan/ post-test (hari ke-30), di mana sampel darah diambil dari bagian ekor tikus. Analisa kadar glukosa darah dilakukan menggunakan glucometer dan serum darah diambil untuk pemeriksaan kadar serum IGF-1 menggunakan ELISA-kit.

Analisis statistic menggunakan SPSS versi 23, uji distribusi data dilakukan dengan uji Shapiro-Wilk dan uji homogenitas data menggunakan uji Levene. Jika data terdistribusi normal, maka dilanjutkan dengan uji one way ANOVA, kemudian dilanjutkan dengan uji Post Hoc Duncan untuk melihat perbedaan antara kelompok. Uji korelasi dilakukan dengan Pearson Correlation.

\section{HASIL PENELITIAN}

Metformin digunakan sebagai obyek dalam penelitian ini untuuk memberikan dukungan ilmiah terhadap informasi efek metformin sebagai obat anti-hiperglikemik, namun tidak mengakibatkan hipoglikemik, karena tidak meningkatkan produksi sel beta pankreas (Lee \& Min, 2013). Pada 
Tabel 2

Rerata Kadar Serum IGF-1 Tikus Putih Jantan Galur Wistar

\begin{tabular}{|c|c|c|c|c|c|c|c|c|c|c|}
\hline \multirow{3}{*}{$\begin{array}{l}\text { Variabel } \\
\text { (waktu) }\end{array}$} & \multicolumn{9}{|c|}{ Kelompok } & \multirow[t]{3}{*}{$p$-value* } \\
\hline & \multicolumn{3}{|c|}{ Kelompok Kontrol (K) } & \multicolumn{3}{|c|}{ Kelompok Restriksi (P1) } & \multicolumn{3}{|c|}{ Kelompok Metformin (P2) } & \\
\hline & Min & Max & Mean \pm SD & Min & Max & Mean \pm SD & Min & Max & Mean \pm SD & \\
\hline Hari ke-0 & 4,91 & 8,22 & $6,94 \pm 1,33$ & 8,59 & 13,67 & $10,34 \pm 1,78$ & 4,77 & 10,12 & $8,02 \pm 2,28$ & 0.018 \\
\hline Hari ke-15 & 5,53 & 9,11 & $7,60 \pm 1,24$ & 9,25 & 15,23 & $11,45 \pm 2,09$ & 6,94 & 13,46 & $10,63 \pm 2,64$ & 0.014 \\
\hline Hari ke-30 & 5,99 & 9,78 & $8,39 \pm 1,56$ & 12,74 & 16,77 & $14.22 \pm 1,46$ & 8,43 & 14,03 & $11,89 \pm 2,51$ & 0 \\
\hline
\end{tabular}

penelitian ini parameter yang diamati adalah perubahan kadar glukosa darah dan kadar serum IGF-1 tikus putih jantan tua galur wistar.

Pada tabel 1 menunjukkan rerata kadar glukosa darah tikus putih jantan tua pre -test, mid-test dan post-test. Perbedaan perlakuan yang diberikan pada masing-masing kelompok bermakna, di mana rerata kadar glukosa darah pre test dan post test tertinggi pada kelompok metformin (P2), sedangkan rerata kadar glukosa pre test terendah pada kelompok kontrol $(\mathrm{K})$ dan post test pada kelompok metformin (P1).

Pada tabel 2 menunjukkan rerata kadar serum IGF-1 tikus putih jantan tua pretest, mid-test dan post-test. Perbedaan perlakuan yang diberikan pada masing-masing kelompok bermakna, di mana rerata kadar serum IGF-1 pre test dan post test tertinggi pada kelompok metformin (P2), sedangkan rerata kadar serum IGF-1 pre test terendah pada kelompok kontrol (K) dan post test pada kelompok metformin (P1).

Pada gambar 1 menunjukkan perbedaan rerata kadar glukosa darah dan kadar serum IGF-1 pada tiap kelompok. Pada grafik menunjukkan adanya perbedaan selisih kadar glukosa darah dan kadar se- rum IGF-1 tiap kelompok percobaan, pada kelompok kontrol $(\mathrm{K})$ terlihat terjadinya peningkatan kadar glukosa darah dengan nilai 46,83 dan pada kelompok restriksi (P1) dan kelompok metformin (P2) mengalami penurunan kadar glukosa darah dengan nilai -24 dan $-18,83$. Kadar serum IGF-1 tertinggi pada kelompok restriksi (P1) dengan nilai 3,87, tidak jauh beda dengan kelompok metformin (P2) dengan nilai 3,86, sedangkan pada kelompok kontrol (K) memiliki kadar serum IGF-1 terendah dengan nilai 1,45 .

\section{PEMBAHASAN}

Proses penuaan merupakan proses kompleks yang tidak bisa dihindari yang ditandai dengan penurunan fungsi berbagai organ tubuh secara bertahap dan peningkatan risiko penyakit (Blokh \& Stambler, 2015; Blokh \& Stambler, 2012; Phillipson, 2014). Perubahan terjadi di mulai pada tingkat molekul (protein, DNA, lipid) sampai pada tingkat seluler dan organ. Secara metabolik proses penuaan terjadi peningkatan kadar glukosa dan insulin yang mengakibatkan terjadinya kondisi kurang sensitif pada sel-sel tubuh terhadap stimulasi insulin (resistensi insulin). Terjadinya 


\section{Gambar 1}

Selisih Rerata Kadar Glukosa Darah dan Kadar IGF-1

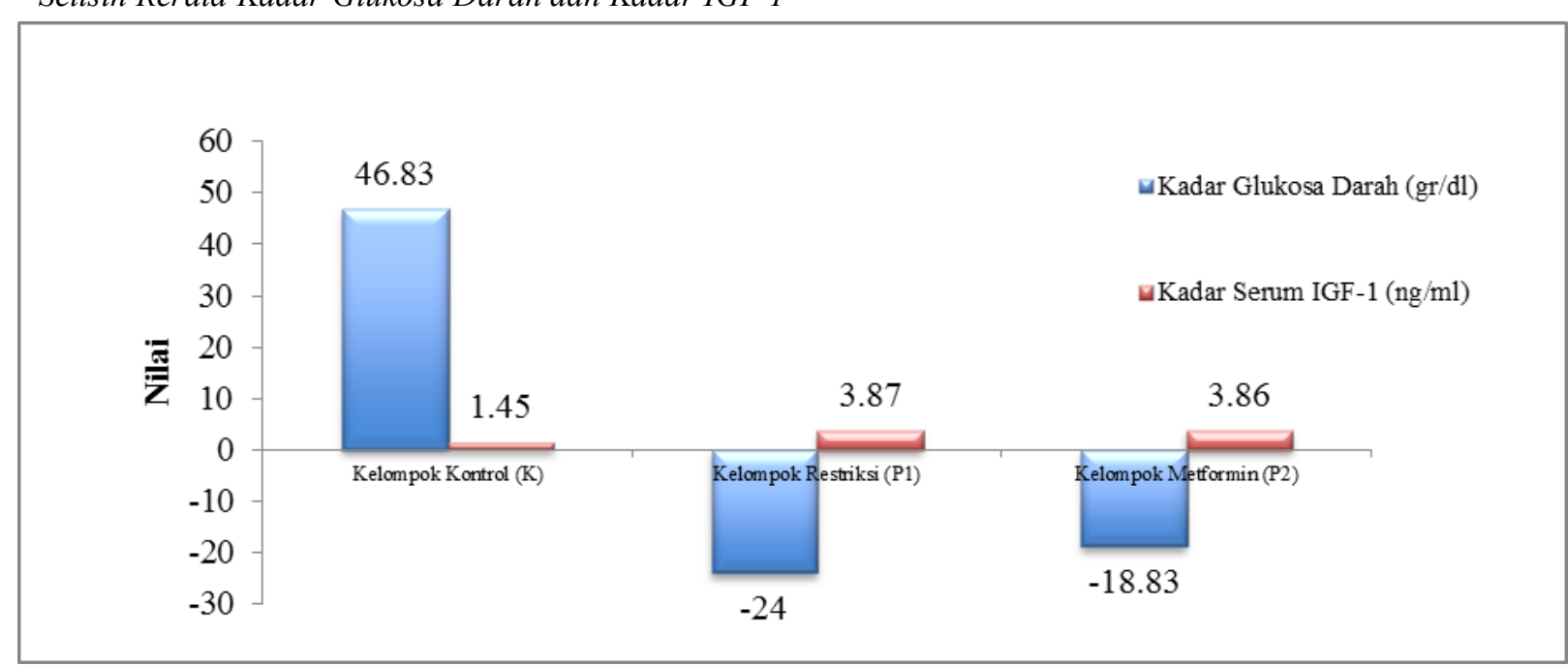

resistensi insulin, di awali ketika sel beta pankreas menyekresi insulin lebih banyak supaya kadar glukosa dalam darah tetap pada kondisi normal. Namun bila sel beta pankreas tidak mampu mengatasi gangguan, baik yang disebabkan oleh faktor eksternal (proses penuaan, gangguan maturasi neonatal, kelaparan, dan lainnya) maupun faktor internal (genetik) maka kondisi ini mengakibatkan terjadinya peningkatan level glukosa darah (Al-Goblan et al., 2014). Selain terjadinya keadaan resistensi insulin, proses penuaan secara metabolik juga menyebabkan perubahan komposisi tubuh dan penurunan fisiologis dari hormon pertumbuhan $(\mathrm{GH})$ dan insulin-like factor-1 (IGF1). Penelitian telah menunjukkan bahwa sistem IGF memainkan peran penting dalam mengatur jalur sinyal tentang penuaan dan penyakit terkait penuaan seperti penyakit kardiovaskular, osteoporosis dan penuaan tulang belakang (Berryman et al., 2008; Li et al., 2017).

Penelitian ini menggunakan metformin sebagai restriksi kalori mimesis dan diet restriksi kalori $30 \%$ sebagai perla- kuannya dengan tujuan melihat efek yang terjadi pada kadar glukosa darah dan kadar serum IGF-1 pada tikus putih jantan tua galur wistar. Dari hasil penelitian didapatkan adanya perbedaan kadar glukosa darah tiap kelompok perlakuan, di mana pada kelompok kontrol $(\mathrm{K})$ terjadi peningkatan kadar glukosa, sedangkan pada kelompok restriksi kalori dan kelompok metformin terjadi penurunan kadar glukosa darah. Bila dilihat dari post hoc uji Duncan menunjukkan bahwa kadar glukosa darah pada kelompok metformin (P2) berbeda tidak nyata dengan kelompok restriksi kalori, namun berbeda sangat nyata dengan kelompok kontrol pada taraf nyata 5\%. Hal ini menunjukkan pemberian restriksi kalori maupun metformin cenderung menurunkan kadar glukosa darah pada tikus. Beberapa data penelitian telah membuktikan bahwa restriksi kalori jangka panjang efektif dalam mencegah berkembangnya resistensi insulin yang dialami pada proses penuaan dengan menurunkan kadar glukosa darah (Smith et al., 2010).

Mekanisme restriksi kalori pada be- 
berapa penelitian yang telah dilakukan menjelaskan beberapa jalur sensor nutrisi (nutrient-sensing signaling pathways), yang penting seperti Insuline-like growth factor-1 (IGF-1), Adenosine Monophosphate-Activated Protein Kinase (AMPK), mechanistic Target-of-Rapamycin (mTOR), dan beberapa turunan sirtuin (SIRT) terutama SIRT-1. Peningkatan konsentrasi kadar serum glukosa setelah adanya asupan makanan merangsang sekresi hormon insulin yang mengaktifkan pensinyalan insulin/IGF-1 (IIS). Pensinyalan ini juga memodulasi proses penuaan (Pan \& Finkel, 2017).

Penggunaan metformin sebagai CRM dianggap tepat karena proses kerja metformin di dalam tubuh yaitu dengan memperbaiki jaringan perifer dan sensitivitas hepar terhadap insulin tanpa berefek pada sekresi insulin. Hal ini terjadi karena efek aktivitas kinase yang ada pada sel (AMP-activated kinase). Metformin bekerja dengan menurunkan pembentukan glukosa di hepar serta meningkatkan sensitivitas adiposa dan jaringan otot pada insulin. Selain itu dapat menurunkan glukosa darah melalui pengaruhnya terhadap kerja insulin pada tingkat selular, menurunkan produksi glukosa hati, meningkatkan pemakaian glukosa oleh sel pada usus sehingga menurunkan glukosa pada darah serta juga diprakirakan dapat menghambat penyerapan glukosa dalam usus sesudah asupan makan. Metformin meningkatkan pemakaian glukosa oleh sel usus sehingga menurunkan glukosa darah (Wati et al., 2014; Nagoy et al., 2019).

Pada penelitian ini didapatkan bahwa pemberian restriksi kalori maupun metformin pada tikus putih tua jantan galur wistar cenderung menurunkan kadar glukosa darah. Penelitian ini sejalan dengan temuan yang diperoleh Wati et al. (2014) dan Mustika et al. (2017) bahwa metformin dapat menurunkan kadar glukosa darah. Penelitian lain menunjukkan tidak terdapat perbedaan yang cukup kuat antara penurunan kadar glukosa darah dengan penggunaan metformin.

Penuaan merupakan proses yang umum dan terjadinya penurunan fungsi berbagai organ secara bertahap. Banyak faktor fisiologis yang berperan penting dalam penuaan, salah satunya adalah IGF-1. Hormon IGF-1 menurun seiring dengan bertambahnya umur. Beberapa temuan telah menunjukkan bahwa sistem IGF memainkan peran penting dalam mengatur jalur sinyal tentang penuaan dan penyakit terkait penuaan seperti penyakit kardiovaskular, osteoporosis dan penuaan tulang belakang (Berryman, 2008; Li et al., 2017).

Pada penelitian ini terdapat perbedaan yang bermakna pada kadar serum IGF -1 antar kelompok kontrol dan kelompok perlakuan, di mana kelompok perlakuan memiliki kadar serum IGF-1 lebih tinggi dibandingkan kelompok kontrol. Bila dilihat dari uji post hoc Duncan, maka kadar serum IGF-1 pada tikus kelompok pemberian metformin (P2) berbeda tidak nyata dengan kelompok restriksi kalori, namun berbeda sangat nyata dengan perlakuan pada kelompok kontrol pada taraf nyata 5\%. Hal ini menujukkan bahwa pemberian restriksi kalori maupun metformin cenderung menaikkan kadar serum IGF-1 
pada tikus putih jantan tua galur wistar. Penelitian ini sejalan dengan penelitian Paolisso et al. (2000) yang menggambarkan peningkatan rasio IGF-1/IGFBP-3 plasma pada orang yang berusia seratus tahun dibandingkan dengan subjek yang berusia lanjut. Mereka berhipotesis bahwa peningkatan rasio ini merupakan indikasi dari bioavailabilitas IGF-1 yang lebih tinggi dalam peningkatan aksi insulin pada orang yang berusia seratus tahun. Namun, hasil penelitian ini berbeda dengan penelitian Arai et al. (2019) menggambarkan serum IGF-1 yang relatif rendah pada populasi orang yang berusia seratus tahun di Jepang dan penelitian López-Lluch \& Navas (2016) yang menyatakan bahwa restriksi kalori akan menurunkan kadar IGF-1 plasma, meskipun dengan intervensi restriksi kalori dapat mencegah atau menunda penuaan. Berdasarkan uji korelasi person menunjukkan ada hubungan signifikan antara kadar glukosa darah dan kadar serum IGF-1 tikus putih tua jantan. Terdapat korelasi kadar glukosa darah dan kadar serum IGF-1 (sig.<0.05) dengan nilai 0,799 (korelasi kuat negatif, di mana pemberian metformin dan restriksi kalori dapat menurunkan kadar glukosa darah namun cenderung menaikkan kadar serum IGF-1.

\section{KESIMPULAN}

Secara umum pemberian metformin dan restriksi kalori berpengaruh terhadap kadar glukosa darah dan kadar serum IGF-1 yang berperan dalam proses penuaan. Pemberian metformin dapat mejadi alternatif dalam menghambat proses penuaan tanpa harus mengurangi jumlah kalori ataupun diet ketat. Akan tetapi pada penelitian ini belum mendapatkan dosis yang efektif dalam menurunkan kadar glukosa namun meningkatkan kadar IGF-1 sehingga penghambatan proses penuaan lebih maksimal.

Dari hasil penelitian yang telah dilakukan, kami menyarankan perlunya diadakan penelitian lebih lanjut untuk menentukan dosis maksimum serta dosis efektif dari metformin untuk menurunkan kadar glukosa darah dan kadar serum IGF-1 yang dapat memperlambat proses penuaan.

\section{DAFTAR PUSTAKA}

Adams, P. D., Jasper, H., \& Rudolph, K. L. (2015). Aging-induced stem cell mutations as drivers for disease and cancer. Cell stem cell, 16(6), 601-612. https://doi.org/10.1016/ j.stem.2015.05.002

Al-Goblan, A. S., Al-Alfi, M. A., \& Khan, M. Z. (2014). Mechanism linking diabetes mellitus and obesity. Diabetes, metabolic syndrome and obesity: targets and therapy, 7, 587. https://dx.doi.org/10.2147\%2FDMSO.S67400

Anderson, R. M., \& Weindruch, R. (2012). The caloric restriction paradigm: implications for healthy human aging. American Journal of Human Biology, 24(2), 101-106. https://doi.org/10.1002/ajhb.22243

Arai, Y., Kamide, K., \& Hirose, N. (2019). Adipokines and aging: findings from centenarians and the very old. Frontiers in endocrinology, 10 , 142. https://doi.org/10.3389/fendo.2019.00142

Balasubramanian, P., Howell, P. R., \& Anderson, R. M. (2017). Aging and caloric restriction research: a biological perspective with translational potential. EBioMedicine, 21, 37-44. https://doi.org/10.1016/j.ebiom.2017.06.015

Barzilai, N., Crandall, J. P., Kritchevsky, S. B., \& Espeland, M. A. (2016). Metformin as a tool to target aging. Cell metabolism, 23(6), 10601065. https://doi.org/10.1016/j.cmet.2016.05.011

Berryman, D. E., Christiansen, J. S., Johannsson, G., Thorner, M. O., \& Kopchick, J. J. (2008). 
Role of the GH/IGF-1 axis in lifespan and healthspan: lessons from animal models. Growth Hormone \& IGF Research, 18(6), 455-471. https://doi.org/10.1016/j.ghir.2008.05.005

Blokh, D., \& Stambler, D. A. (2012). The intersection between aging and cardiovascular disease. Circulation research, 110(8), $1097-$ 1108. https://doi.org/10.1161/CIRCRESAHA.111.2 46876

Blokh, D., \& Stambler, I. (2015). Information theoretical analysis of aging as a risk factor for heart disease. Aging and disease, 6(3), 196. https://dx.doi.org/10.14336\%2FAD.2014.062 3

Burch, J. B., Augustine, A. D., Frieden, L. A., Hadley, E., Howcroft, T. K., Johnson, R., \& Wise, B. C. (2014). Advances in geroscience: impact on healthspan and chronic disease. Journals of Gerontology Series A: Biomedical Sciences and Medical Sciences, 69(Suppl_1), S1-S3. https://doi.org/10.1093/gerona/glu041

Čepelak, I., Dodig, S., \& Dodig, D. C. (2019). Aging, Calorie Restriction and Calorie Restriction Mimetics. Rad Hrvatske akademije znanosti $i$ umjetnosti. Medicinske znanosti, $(540=48-49), \quad 41-50$. https://doi.org/10.21857/9e31 lhnddm

Cerf, M. E. (2013). Beta cell dysfunction and insulin resistance. Frontiers in endocrinology, 4, 37. https://doi.org/10.3389/fendo.2013.00037

Gillespie, Z. E., Pickering, J., \& Eskiw, C. H. (2016). Better living through chemistry: caloric restriction (CR) and CR mimetics alter genome function to promote increased health and lifespan. Frontiers in Genetics, 7, 142. https://doi.org/10.3389/fgene.2016.00142

Graham, N. A., Tahmasian, M., Kohli, B., Komisopoulou, E., Zhu, M., Vivanco, I., \& Graeber, T. G. (2012). Glucose deprivation activates a metabolic and signaling amplification loop leading to cell death. Molecular systems biology, $\quad 8(1), \quad 589$. https://doi.org/10.1038/msb.2012.20

Guerville, F., Barreto, P. D. S., Ader, I., Andrieu, S., Casteilla, L., Dray, C., \& Vellas, B. (2020). Revisiting the hallmarks of aging to identify markers of biological age. The Journal of prevention of Alzheimer's disease, $\quad 7(1), \quad 56-64$. https://doi.org/10.14283/jpad.2019.50

Harianja, E., Widijanti, A., Arsana, P. M., \& Handono, K. (2018). Pengaruh Restriksi Kalori Terhadap Kadar Hidrogen Peroksida Dan Kadar Glukosa Darah Pada Tikus Tua. Indonesian Journal Of Clinical Pathology And Medical Laboratory, 14(1), 24-27. http://dx.doi.org/10.24293/ijcpml.v14i1.921

Johnson, M. (2012). Laboratory mice and rats. Labome.

http://dx.doi.org/10.13070/mm.en.2.113

Lee, P. G., \& Halter, J. B. (2017). The pathophysiology of hyperglycemia in older adults: clinical considerations. Diabetes Care, 40(4), 444-452. https://doi.org/10.2337/dc16-1732

Lee, S. H., \& Min, K. J. (2013). Caloric restriction and its mimetics. BMB reports, 46(4), 181 https://dx.doi.org/10.5483\%2FBMBRep.201 3.46.4.033

Li P., Sun X., Cai G., \& Chen X. (2017). Insulinlike Growth Factor System and Aging. Journal of Aging Science. 5(1). 1-5. https://doi.org/10.4172/2329-8847.1000171

Longo, V. D., Antebi, A., Bartke, A., Barzilai, N., Brown $\square$ Borg, H. M., Caruso, C., \& Fontana, L. (2015). Interventions to slow aging in humans: are we ready?. Aging cell, 14(4), $497-$ 510. https://doi.org/10.1111/acel.12338

López $\square$ Lluch, G., \& Navas, P. (2016). Calorie restriction as an intervention in ageing. The Journal of physiology, 594(8), 2043-2060. https://doi.org/10.1113/JP270543

López-Otín, C., Blasco, M. A., Partridge, L., Serrano, M., \& Kroemer, G. (2013). The hallmarks of aging. Cell, 153(6), 1194-1217. https://doi.org/10.1016/j.cell.2013.05.039

Madeo, F., Carmona-Gutierrez, D., Hofer, S. J., \& Kroemer, G. (2019). Caloric restriction mimetics against age-associated disease: targets, mechanisms, and therapeutic potential. Cell metabolism, 29(3), 592-610. https://doi.org/10.1016/j.cmet.2019.01.018

Madiraju, A. K., Qiu, Y., Perry, R. J., Rahimi, Y., Zhang, X. M., Zhang, D., \& Shulman, G. I. (2018). Metformin inhibits gluconeogenesis via a redox-dependent mechanism in vivo. Nature medicine, 24(9), 1384-1394 https://doi.org/10.1038/s41591-018-0125-4

Mustika, A., Indrawati, R., \& Sari, G. M. (2017). 
Efek Ekstrak Daun Singawalang (Petiveria alliacea) dalam Menurunkan Kadar Glukosa Darah melalui Peningkatan Ekspresi AMPKa1 pada Tikus Model Diabetes Melitus. Jurnal Farmasi Klinik Indonesia, 6(1), 22-31.

https://doi.org/10.15416/ijcp.2017.6.1.22

Nangoy, B. N., de Queljoe, E., \& Yudistira, A. (2019). Uji Aktivitas Antidiabetes Dari Ekstrak Daun Sesewanua (Clerodendron squamatum Vahl.) Terhadap Tikus Putih Jantan Galur Wistar (Rattus norvegicus L.). Pharmacon, 8(4), 774-780. https://doi.org/10.35799/pha.8.2019.29353

Niccoli, T., \& Partridge, L. (2012). Ageing as a risk factor for disease. Current biology, 22(17), R741-R752.

https://doi.org/10.1016/j.cub.2012.07.024

Pan, H., \& Finkel, T. (2017). Key proteins and pathways that regulate lifespan. Journal of Biological Chemistry, 292(16), 6452-6460. https://doi.org/10.1074/jbc.R116.771915

Paolisso, G., Barbieri, M., Bonafe, M., \& Franceschi, C. (2000). Metabolic age modelling: the lesson from centenarians. European journal of clinical investigation, 30(10), 888-894. https://doi.org/10.1046/j.13652362.2000.00729.x

Phillipson, O. T. (2014). Management of the aging risk factor for Parkinson's disease. Neurobiology of aging, 35(4), 847-857.

Podhorecka, M., Ibanez, B., \& Dmoszyńska, A. (2017). Metformin-its potential anti-cancer and anti-aging effects. Advances in Hygiene \& Experimental Medicine/Postepy Higieny $i$ Medycyny Doswiadczalnej, 71. https://doi.org/10.4161/cc.26928

Smith Jr, D. L., Elam Jr, C. F., Mattison, J. A., Lane, M. A., Roth, G. S., Ingram, D. K., \& Allison, D. B. (2010). Metformin supplementation and life span in Fischer-344 rats. Journals of Gerontology Series A: Biomedical Sciences and Medical Sciences, 65(5), 468-474. https://doi.org/10.1093/gerona/glq033

Solon-Biet, S. M., Mitchell, S. J., de Cabo, R., Raubenheimer, D., Le Couteur, D. G., \& Simpson, S. J. (2015). Macronutrients and caloric intake in health and longevity. The Journal of endocrinology, 226(1), R17. https://dx.doi.org/10.1530\%2FJOE-15-0173

Sonntag, W. E., Lynch, C. D., Cefalu, W. T., Ingram, R. L., Bennett, S. A., Thornton, P. L., \& Khan, A. S. (1999). Pleiotropic effects of growth hormone and insulin-like growth factor (IGF)-1 on biological aging: inferences from moderate caloric-restricted animals. Journals of Gerontology Series A: Biomedical Sciences and Medical Sciences, 54(12), B521-B538. https://doi.org/10.1093/gerona/54.12.B521

Stekovic, S., Hofer, S. J., Tripolt, N., Aon, M. A., Royer, P., Pein, L., \& Madeo, F. (2019). Alternate day fasting improves physiological and molecular markers of aging in healthy, non-obese humans. Cell metabolism, 30(3), 462-476.

https://doi.org/10.1016/j.cmet.2019.07.016

Vitale, G., Salvioli, S., \& Franceschi, C. (2013). Oxidative stress and the ageing endocrine system. Nature Reviews Endocrinology, 9(4), 228-240.

https://doi.org/10.1038/nrendo.2013.29

Wati, A., Kosman, R., \& Lizikri, A. (2014). Perbandingan Efektivitas Hipoglikemik Obat Metformin Paten Dan Generik Berlogo Berdasarkan Penurunan Kadar Glukosa Darah Mencit (Mus Musculus) Jantan Yang Diinduksi Aloksan. As-Syifaa Jurnal Farmasi, 6(1), 91-97. https://doi.org/10.33096/jifa.v6i1.37

Xia, S., Zhang, X., Zheng, S., Khanabdali, R., Kalionis, B., Wu, J., \& Tai, X. (2016). An update on inflamm-aging: mechanisms, prevention, and treatment. Journal of immunology research, 2016. https://doi.org/10.1155/2016/8426874

Yudiarto, F. L., \& Sjahrir, H. (2011). Proses Penuaan Otak-Bagaimana Kita Bisa Mencegahnya?. Neurona $\quad$ : $\quad 28$ http://www.neurona.web.id/paperdetail.do? $\mathrm{id}=762$ 